\title{
Conflict of Ethics: Indigenous Americans and Settler Colonists Conflicto de ética: Los pueblos indígenas y los colonos en las Américas
}

\author{
Jürgen Poesche \\ ORCID ID 0000-0003-3571-9157 \\ jurgen.poesche@hotmail.com
}

\author{
Cita recomendada: \\ POESCHE, J. (2020). Conflict of Ethics: Indigenous Americans and Settler Colonists. Eunomía. Revista en \\ Cultura de la Legalidad, 18, pp. 29-47. \\ doi: https://doi.org/10.20318/eunomia.2020.5262
}

Recibido / received: 27/11/2019

Aceptado / accepted: 08/03/2020

\begin{abstract}
The objective of this paper is to develop and present a novel approach to the conflict of ethics on the foundation of legal theory, particularly the legal rules governing conflict of laws. The focus is on the conflict of ethics impacting Indigenous Americans in the context of Occidental settler colonialism in the Americas. This paper contains three major contributions. First, the interplay between Indigenous American concepts categorized as ethics in the Occident and Occidental ethics in a settler colonial context was assessed. Second, Occidental concepts in Roman Law and Saint Thomas Aquinas' natural law was used to determine the precedence of Indigenous American equivalents to ethics vis-à-vis Occidental ethics in the Americas. Third, rules-based solutions synthetized from conflict of laws in international law were applied to conflict of ethics in the settler colonial context in the Americas.
\end{abstract}

\section{Keywords}

Cultural and epistemic racism, decoloniality, indigenous Americans, settler colonialism, sumak kawsay, wakohtowin.

\section{Resumen}

El objetivo de este artículo es desarrollar y presentar un enfoque novedoso del conflicto de ética sobre la base de la teoría legal, particularmente las reglas legales sobre el conflicto de leyes. La atención se centra en el conflicto de ética que afecta a los indígenas en el contexto del colonialismo en las Américas. Este artículo contiene tres contribuciones principales. Primero, se evaluó la interacción entre los conceptos de los indígenas categorizados como ética en el occidente en el contexto colonial. Segundo, los conceptos occidentales en la ley 
romana y la ley natural de Santo Tomás de Aquino se usaron para determinar la procedencia de los equivalentes indígenas en las Américas. Tercero, las soluciones basadas en reglas sintetizadas a partir del conflicto de leyes en el derecho internacional se aplicaron al conflicto de ética en el contexto colonial en las Américas.

\section{Palabras clave}

Racismo cultural y epistémico, descolonialidad, indígenas en las Américas, colonialismo, sumak kawsay, wakohtowin

SUMMARY. 1. Introduction. 2. Conflict of laws. 2.1. Roman law and Occidental legal families. 2.2. International private and public law. 2.3. Indigenous American equivalent of law. 3. Indigenous American Concepts. 4. Navigating Conflict of Ethics. 5. Conclusion. References.

\section{Introduction}

The objective of this paper is to develop and present a novel approach to the conflict of ethics on the foundation of legal theory, particularly the legal rules governing conflict of laws. The need to address the conflict of ethics stems from the increasing importance of particularly the Indosphere and Sinosphere with their respective cultures and epistemes on the one hand, and recognition of Indigenous cultures and epistemes in intrastate law -highlighted by legal pluralism- and interstate law -epitomized by the United Nations Declaration on the Rights of Indigenous Peoples. The need for addressing the conflict of ethics is further underlined by problems associated with the legality and legitimacy of settler colonial states' sovereignty claims.

The focus of this paper is on the conflict of ethics impacting Indigenous Americans. This paper fills a gap in the literature by bringing together legal concepts used in solving conflicts of laws in international law, and cultural and epistemic racism in the context of a clash of Indigenous American concepts categorized as ethics in the Occident and Occidental ethics. The characteristics and dynamics of the settler colonialism Indigenous Americans have been subjected to cannot be assumed to be same as in the colonialism in Africa and Asia. In the context of the colonial experience of Indigenous Americans, the terms "internal colonialism" and "settler colonialism" have been used by, e.g., Churchill (1985, p. 35). The idiosyncrasies of settler colonialism impact the choice of literature in this paper.

The term "Occident" is used instead of "the West", because the latter needs to be rejected: "The West" is both ahistorical and ambiguous. E.g., "the West" ( لمغرب ) refers to the Maghreb countries in Arabic, and "the West" (西域) has historically referred to Central Asia in Chinese. In this paper, the term "Occident" refers to societies that are founded on the Greco-Roman Heritage -including Roman Law-and Occidental Christianity -Roman Catholicism and Protestantism. Occidental ethics is understood to be ultimately founded on ancient Greek philosophical ethics that has been influenced by, e.g., Saint Augustine of Hippo on the basis of Occidental Christian theology.

Although discrimination generally and discrimination directed against individual groups in particular have been studied in, e.g., Montargot and Peretti (2014, p. 187), and Coelho (2019, pp. 1993-1995), conflict of ethics as it relates to the incompatibility 
of Indigenous American concepts categorized as ethics in the Occident and Occidental ethics with their Occidental equivalents has received limited attention. The foundations of Indigenous American concepts categorized as ethics in the Occident are the different Indigenous American cosmovisions (León-Portilla, 1983, p. 22). The original foundation of Occidental ethics was ancient Greek ethical philosophy (Gérard, 2012, p. 205), but it was reformulated and reinterpreted on the basis of Occidental Christian theology.

The incompatibility of Indigenous American concepts categorized as ethics in the Occident and Occidental ethics are exemplified by two legitimations. First, ethics derived from Occidental Christianity was used to legitimize the destruction of Indigenous American cultures (Estrada, 2006, pp. 8-9). Second, ethics derived from Occidental Christianity was used to legitimize the enslavement of Indigenous Americans in the $15^{\text {th }}$ and $16^{\text {th }}$ centuries (Mayer, 2014, pp. 1128-1129). The terms "ethics" and (religious) "morals" are considered a purely nominalist issue, and consequently they are used interchangeably in this paper.

The development of concepts dealing with conflict of ethics does not need to start from nothing. In international private and public law, concepts dealing with conflict of laws have been developed over the centuries, e.g., Salah $(2010$, p. 31). Two caveats are in place. First, the categories "ethics" and "law" are of Occidental origin and are thus not meaningful outside of the Occident. Second, the concepts dealing with conflict of laws have been developed within the confines of the Occidental legal families -and ultimately Roman Law- and are therefore inapplicable outside of these confines. Nevertheless, the concepts dealing with conflict of laws are a useful starting point.

A search for the universal may effectively put pressure on Indigenous Americans to adopt and emphasize factors congruent with the dominant ethics -the Occidental ethics. This would reduce conflicts of ethics, but it also contains the seed of racism, and cultural and epistemic racism.

Recognizing the multiplicity of descriptions of racism, Memmi's (2000, p. 169) description is adopted for the purposes of this paper: "Racism is the generalized and final assigning of values to real or imaginary differences, to the accuser's benefit and at his victim's expense, in order to justify the former's own privileges or aggression" (Grosfoguel, 2004, p. 315) has raised the issue of the problems with (cultural) ethnicity versus (biological) race. A narrow definition of racism as being about the biological race alone would effectively legitimize cultural (and epistemic) racism. Cultural and epistemic racism is about the negation (Orellana F., 2005, p. 87) or peripheralization (Pachón Soto, 2012, p. 47) of another culture and episteme.

Remedying eurocentrism involves decolonial and intercultural dialogues between different cultures and epistemes, including the Indigenous American cultures and epistemes (Quijano, 2007, pp. 106-107). The phenomenon of cultural genocide ethnocide means that Indigenous Americans are prevented from using, developing and teaching their own cultures- taking advantage of the institutional and legal power structures of the state has been connected to the settler colonialism found in the Americas (Mako, 2012, pp. 176-180).

This conceptual paper is divided into five sections. In order to set the stage for a synthesis for handling conflict of ethics, the second section addresses conflict of laws. In the three subsections of the second section, Roman Law and the Occidental legal families, international private and public law, and current force of Indigenous American equivalents of law are studied. In the third section, Indigenous American 
concepts categorized as ethics in the Occident are investigated. In the fourth section, ways to navigate fundamentally incompatible Indigenous American and Occidental concepts in the field referred to as ethics in the Occident are synthetized. Additionally, the first section contains the Introduction and the fifth section the Conclusion.

\section{Conflict of laws}

In the aftermath of 1492, the Occident took measures that effectively prevented the possibility of conflict of laws by destroying the Indigenous American nations. The conquest and hence all subsequent actions were not only illegal and illegitimate from an Indigenous American perspective, but also from an Occidental Natural Law perspective. The efforts of Bartolomé de las Casas and Francisco de Vitoria to limit the encroachments on the rights of Indigenous Americans are well known albeit the former argued that the Indigenous Americans were inferior to the Occidentals (Rosa, 2015, p. 260). Another person deserves to be mentioned: Alonso de la Vera Cruz, the first professor of theology at the Real y Pontificia Universidad de México after the Spanish conquest, admitted in De dominio infidelium et justo bello that was founded on Natural Law developed by Saint Thomas Aquinas and ius gentium -both of Occidental pedigree- that the conquest of the Americas was a fait accompli in spite of being illegal (Westra, 2011, pp. 100-107). A fait accompli is a problematic legal argument in Roman Law, because theft prevents usucapio, and thus an establishment of a fait accompli.

A challenge in an attempt to reduce cultural and epistemic racism is Pfordten's (2012, p. 456) argument that concepts are more important in laws than norms. On the one hand, concepts are not universal and the use of Occidental concepts to study Indigenous American equivalents to ethics and law is bound to result in failure, a failure that could be misused in calls for universal validity of Occidental ethics and law. On the other hand, a focus on concepts requires scholars to understand the cultural context of laws.

The work of Saint Thomas of Aquinas was founded on an Occidental understanding of Natural Law (Roca, 1997, p. 883), and hence his scholarship was limited by the Greco-Roman Heritage and Occidental Christianity. This intercultural critique of Saint Thomas of Aquinas' scholarship is fundamentally different from the intracultural critique in, e.g., Massini-Correas (2019, p. 12). Ary (2014, pp. 542-543) has propounded that law both constructs and reflects the ethics in a historically evolved society. Saint Thomas of Aquinas' Natural Law thus arguably had and has some force in the Occident and an Occidental state's deportment vis-à-vis Indigenous American nations, but it had and has no legitimacy in Indigenous American nations.

Because the criteria used for statehood were modelled on European ideas on political and social organization, it was difficult for Indigenous American political entities to be recognized as states after the Peace of Westphalia in 1648. The resulting lack of statehood is ontologically problematic when solutions for conflict of ethics are developed founded on the example of conflict of laws. To circumnavigate this problem, Indigenous American political entities -in a wide sense- are referred to as nations and Occidental political entities as states in this paper.

Whereas the manifold Indigenous American conceptions and interconnections of what is categorized as ethics and law in the Occident differ from those found in the Occident concepts- including international private and public law- any assessment and synthesis of conflict of laws and conflict of ethics is a complex undertaking. Ollero's (2002, pp. 270-271) rejection of the separation of ethics and law that has occurred in Occidental legal positivism suggests that Occidental categorizations are 
not considered optimal even in the Occident. Furthermore, Estrada Ochoa (2009, pp. 190-192) shows the complexity flowing from different categorizations.

The failure of the Occident to submit to the -arguably only legal and legitimateIndigenous American concepts of what are categorized as ethics and law in the Occident in the Americas in the aftermath of 1492 raises the issue of possible faults in the Occidental conceptualization of equality. A fundamental rejection of Indigenous American concepts by the settler colonists effectively prevents reciprocity between the Indigenous Americans and settler colonists, and this casts doubt on the settler colonists' willingness to consider the Indigenous Americans as equals on the basis of Aristotle (Perrin, 2007, pp. 279-280). Occidentals considered the Indigenous American inferior using Aristotle's conceptualization -as epitomized by Bartolomé de las Casasthus purportedly legitimizing an appalling treatment of Indigenous Americans, and the destruction of Indigenous American cultures and epistemes in the Americas.

The Weberian view of formal rationality that legitimizes unequal treatment when this is appropriate and proportionate against the backdrop of a recognized objective (Renner, 2010, p. 163) can result in the legitimization of racism. A recognized objective may very well be racist, and culturally and epistemically racist as demonstrated by the objectives recognized by the Occidentals in the aftermath of 1492. The Weberian view is ethically troubling, because it suggests that racism, and cultural and epistemic racism can be considered rational by the Occident.

Because of the fragmentation of critical legal studies (Oberkofler, 2006, pp. 210-211), critical theory does not offer a promising path forward in the study of conflict of laws, and conflict of ethics. However, the scholarship of Bartolomé de las Casas, Alonso de la Vera Cruz and Francisco de Vitoria indicates that the Occident is not necessarily hostage to racism, and cultural and epistemic racism perpetrated against Indigenous Americans. To identify Occidental ethics that have not been tainted by political expediency and religious fanaticism, it is necessary to go back in history -to the Roman Empire. The principles found in Roman Law are used as an approximation of Occidental substantive ethics.

\subsection{Roman law and Occidental legal families}

To begin with, it is warranted to consider the influence of Roman Law in the Occident today. This is complicated by the historical development that gave rise to two Occidental legal families. The division into the common law family that encompasses the former of the British Empire on the one hand and the Civil Law family on the other hand is consequential, because only the latter unequivocally descends from Roman Law (Guénaire, 2001, p. 49). Common law is found in Antigua and Barbuda, Bahamas, Barbados, Belize, British Virgin Islands, most of Canada, Cayman Islands, Dominica, Grenada, Jamaica, Saint Kitts and Nevis, Saint Vincent and the Grenadines, and most of the USA in the Americas. The other countries in the Americas belong to the Civil Law family with its roots in Roman Law.

Although the nexus between common law and Roman Law is tenuous, common law has been influenced by Roman Law particularly in four ways. First, there was an attempt to create a uniform canon and laic law that prevented any clear demarcation between the two in the Middle Ages (Müller, 2006, pp. 1-16) -at a time when England still recognized the ecclesiastical supremacy of the Pope. Second, a significant influence of the Decretum Gratiani (about AD 1140) extended to the Anglican Church. Third, the Court of Chancery of England was established in the context of a wider reception of Roman Law in the Occident albeit this reception was 
limited in England (Macnair, 2007, p. 663). Fourth, the broader classical culture and philosophical reception impacted also English society.

There is disagreement in the literature regarding the strength of the influence of Roman Law on contemporary law in the Civil Law family. On the one hand, Villey (2002, p. 113), among others, has argued that there is a significant influence. On the other hand, Gaviria Gil (2013, p. 53) has even questioned the contemporary existence of a Civil Law family because of ongoing changes -among them the incorporation of a legal pluralism that allows for the recognition of Indigenous American laws. In the civil law family, there has been a significant interaction between canon law and secular law in addition to a nexus between ethics and Roman Law (Zimmermann, 2007, p. 9). The -at least initial- discussion regarding ethics versus law goes back to the beginnings of the Greco-Roman Heritage, specifically Aristotle (Winkel, 2015, pp. 343345). Later, Aristotle's work formed the intellectual foundation for Saint Thomas of Aquinas and the Spanish natural law scholars in the $16^{\text {th }}$ and $17^{\text {th }}$ centuries (Kohler, 1917 , p. 235) -among them was Bartolomé de las Casas.

Exclusivity is not a trait that can be associated with Roman Law. Although still controversially debated, there seem to have been provincial laws differing from each other and differing from Roman Law in the Roman Empire, and with the disintegration of the Roman Empire there was some degree of dynamically changing ethnic legal particularism in the Germanic kingdoms (Le Goff, 2008, pp. 25-28). As the Roman Empire disintegrated in the $4^{\text {th }}$ and $5^{\text {th }}$ centuries, Germanic foederati established effectively independent realms on (former) Roman territory. Parallel legal systems existed for the Germanic migrants (foederati) and Romans living in the same territory -a system focussing on the person- to be replaced eventually by a territorial system (Olivier-Martin, 2010, pp. 26-27).

Why did the Occidentals not submit themselves to the -arguably only legal and legitimate- Indigenous American concepts which are categorized as law in the Occident in the aftermath of 1492? Apart from Occidental religious zealotry, an explanation can be sought in the association of legal particularism with the Occidental weakness that resulted in the Occident's defeat in the Crusades and the rejection of legal particularism as the Renaissance gathered pace.

Going forward, the historical template of legal particularism in and after the disintegration of the Roman Empire legitimizes ethical particularism from an Occidental perspective. Legal particularism engenders the need to devise ways to deal with conflict of laws. Solutions have been developed in international private and public law.

\subsection{International private and public law}

Emanuelli $(2010$, p. 2) has observed that the philosophical foundation of international relations has its roots in the Greco-Roman Heritage. Gschwend $(2009$, p. 52) has noted that the foundation of human rights law can be found in the work done in the Faculty of Law at the University of Salamanca in the $15^{\text {th }}$ century. The refusal to grant sovereignty to Indigenous nations (Emanuelli, 2010, pp. 245-247) -a stance that has been criticized in the literature (Fox-Decent and Dahlman, 2015, pp. 532-533)- may be interpreted as corroboration for cultural and epistemic racism in extant international public law. Ingrained in human rights law is a discriminatory cognitive elitism that contains the view that cultures and epistemes are unequal, because the place of humans in Nature follows the Occidental view that is fundamentally incompatible with, e.g., Sumak Kawsay. 
An attempt to address cultural and epistemic racism in international private law and international public law within the Occidental confines needs to consider legal history and legal theory. Hans Kelsen's legal positivism effectively renders enforceable law a product of the extant societal power structures. If these societal power structures are illegal or illegitimate for, e.g., historical reasons, then the enforceable law becomes a tool of injustice and oppression, including cultural and epistemic racism. If an exploitation of law for injustice and oppression is to be avoided, then one of four stratagems can be pursued within the confines of the Occidental culture and episteme. First, positive law tainted by injustice and oppression is quashed, and the status quo prior to the subversion is reinstated -the year 1492 would represent a tentative watershed. Second, Natural Law could be resorted to- the year 1492 would again represent a tentative watershed. Third, Customary Law could be broadened to encompass Indigenous American concepts categorized as law in the Occident. Fourth, the focus could be on processual norms particularly in the forms of democratic, Habermasian and Rawlsian processes instead of substantive norms -the issue here would be that this would encourage genocide and cultural genocide as a way to achieve democratic legitimation.

From the standpoint of legal history and particularly legal theory, international private law and international public law are distinct. It is ultimately impossible to delineate international private law from international public law as the result of international private law relying heavily on attributes of the legal systems in question that are (also) part of public law, e.g., interstate treaties governing matters governing matters related to private law.

In spite of the United Nations Declaration on the Rights of Indigenous Peoples, the influence of the Indigenous nations in international law has not significantly increased, because the legal theory used in its interpretation is still the same with its roots in Roman Law. Albeit it is accurate that Indigenous American nations have gained some jurisdictional ground in international private law as a result of legal pluralism in several Latin America states (Díaz Ocampo and Antúnez Sánchez, 2018, p. 59), and in international public law (Díaz Ocampo and Antúnez Sánchez, 2018, p. 47 ), this is taking place against the backdrop of a continued predominance of Occidental law. The refusal to recognize the sovereign status of Indigenous American nations deprives them of a meaningful participation in the enforcement and formulation of international public law in particular. In this context, reading, e.g., Becerra Ramírez (2017, in toto) is interesting for what is missing: The current Occidental dominance in international law is not seriously questioned.

Indigenous collective rights have received attention in international public law only relatively recently -the first generation of human rights law dealt with civil and political rights, the second with economic and social rights, and the third with collective rights (Quintana Osuna and Góngora Maas, 2017, pp. 1-2). The 2007 United Nations Declaration on the Rights of Indigenous Peoples creates the foundation in international law for the recognition of Indigenous American concepts categorized as ethics and law in the Occident. A conceptual challenge is that international law was founded on the dichotomy of state and individual, but groups -among them Indigenous American nations- were recognized only in the aftermath of the bulk of decolonization in Africa and Asia in the 1960s -i.e., two continents with relatively limited experiences with settler colonialism.

Problems persist. Occidental political expediency is epitomized by the 1948 United Nations Convention on the Prevention and Punishment of the Crime of Genocide -a convention substantively contrived by the Occidental colonial powers. The protection of individual and group rights have long been contradictory as they 
relate to cultural and epistemic diversity in international (public) law, because the Occident has prioritized individual rights while many Indigenous Nations have emphasized rights as a part of Nature -Nature encompasses spirits, animate beings, among them humans, and inanimate "objects". The Occidental term "group rights" does therefore not grasp this fundamental contradiction. This failure suggests moreover that there has been a retrograde development in the Occident, because the Roman Empire and Roman Law accepted legal pluralism: Non-Roman legal orders were tolerated in the provinces (Lepelley, 1998, pp. 84-85).

Cultural genocide targeting Indigenous American nations may include Indigenous American customs categorized as Customary Law in the Occident. A prime difference between ethics and law is that ethics can be equated with customs, and customs -or Customary Law- are only one source in Occidental law. Whether a similar difference exists in Indigenous American nations is doubtful. If such a difference does not exist, then any imposition of Occidental law is also an ethical issue when Occidental categorizations are used.

In international private law, Soft Law (Pereznieto Castro, 2015, pp. 795-797) may contain cultural and epistemic racism, but Soft Law could aösp offer an avenue to incorporate Indigenous concepts (Bermúdez Abreu and Quintero, 2007, p. 45). Realistically, this must be doubted. In view of the extant economic power structures in addition to asymmetries in judicial enforcement in the Americas, Soft Law favours Occidental laws and disadvantages Indigenous American concepts categorized as law in the Occident. An avenue to strengthen the position of Indigenous American concepts categorized as law in the Occident is the adoption of legal pluralism in addition to granting sovereignty to Indigenous American nations.

The available space does not allow for a comprehensive assessment of conflict of laws in international private and public law. Therefore, the assessment is limited to the principles of nationality versus territoriality, judicial restraint, transnationalism, ordre public, act of state, renvoi, proximité, and ius cogens.

In international law, the status of international law vis-à-vis domestic law is a contentious issue. The old-fashioned assumption that conflicts of laws solely occur in the context of international private law as a result of states having only one domestic legal system, e.g., Silva Alonso (1972, pp. 362-363), is problematic in states characterized by settler colonialism. Effectively, the old-fashioned assumption means that Indigenous American equivalents of law have been ignored by the settler colonists in the Americas. Theoretically, two extreme positions on a continuum are represented by the strict dualists and the monists with the former arguing that international law and domestic law are rigorously separated, and the latter maintaining that the two form a unity (Tuori, 2013, p. 11). Strict dualism applied to settler colonial states in the Americas raises challenging issues regarding nationality versus territoriality, because there would be one or several Indigenous American concepts categorized as law in the Occident in addition to Occidental law to be enforced in the same territory. In a situation characterized by international law, one settler colonial state law, and at least one Indigenous American nation's equivalent of law, the assumptions underpinning strict dualism would be invalid. This leaves issues relating to the determination of the applicable procedural and substantive law open.

Extant monism is problematic, because monism would introduce Occidental law into Indigenous American equivalents of law when the former is applied as a result of extant international private and public law having Greco-Roman roots (Giesen, 2013, pp.411-438). Implementing monism on the foundation of Indigenous American 
concepts categorized as law in the Occident would probably cause resistance among the settler colonists.

A path forward would be that Indigenous American nations' concepts categorized as law in the Occident are recognized in international private law and international public law irrespective of settler colonial state boundaries. In intrastate cases, conflicts of law between an Indigenous American nation's concepts categorized as law in the Occident and a settler colonial state would be resolved on the foundation of the conflict of law rules found in international private law and international public law.

A challenge in international private law is the determination of the applicable law. This determination may be founded on, e.g., domicile, habitual residence or nationality. It is thus an issue of nationality versus territoriality. Nationality versus territoriality is one of the most vexing challenges when Indigenous American equivalents of law are granted legal force in states. It is warranted to emphasize two points. First, both nationality and territoriality are compatible with the history of Roman Law, and thus legitimate in the Occident. Second, the illegality and illegitimacy of the conquest of the Americas by the Occidentals determined by Alonso de la Vera Cruz and Francisco de Vitoria in association with Roman Law means that territoriality would result in Indigenous American equivalents of law being the only valid law in their respective territories -as the territories stood before 1492 .

The challenges associated with nationality versus territoriality are highlighted in Bolivia: The use of Indigenous American equivalents of law have been restricted to Indigenous American territories (Camacho Negrete, 2012, p. 173). This means that Indigenous Americans living in the cities outside of their national territory are subjected to Occidental law. This effectively creates two classes of Indigenous Americans. Another challenge is that territoriality can be used to cement coloniality outside of current Indigenous American territories.

Although legal coloniality has received attention in the literature (Garzón López, 2018, pp, 210-212), the incorporation of Indigenous American concepts categorized as law in the Occident into Occidental procedural and substantive law has proven challenging (Romero Seguel, 2012, pp. 821-823). This is not all. Because Occidental judges are products of the Occidental culture and episteme, it must be questioned, whether they possess the capabilities to apply and comprehend the Indigenous American concepts categorized as law in the Occident. This results in the phenomenon that could already be observed in the Roman Empire: The Roman legati Augusti, prefects, proconsuls and procurators resorted to Roman Law when called to adjudicate in the provinces. A complete separation of the courts is thus necessary to eliminate a continuation of coloniality.

The principle of judicial restraint or abstention means that a court in Country A does not adjudicate matters arising in Country $B$ when these matters are of sovereign, international or interstate nature. This principle could be extended to the relationship between states and nations thus creating firewalls between Indigenous American jurisdictions and Occidental jurisdictions.

The somewhat ambiguous principle of ordre public (public policy doctrine) limits the application of the laws of Country $B$ relating to Country $B$ when adjudicated by courts in Country A, when the laws of Country B run counter to the accepted societal norms -including ethics- in Country A (Salah, 2010, p. 31). This would allow Indigenous American equivalents of courts to refuse to apply Occidental laws violating Indigenous American concepts categorized as ethics and laws in the Occident. The 
principle of ordre public, i.e., the ethical societal values underpinning a legal system, is a two-edged sword. On the one hand, it limits the application of Indigenous American concepts categorized as law in the Occident to Indigenous American nationals or nations. On the other hand, it prevents the use of Occidental law on Indigenous American nationals or nations.

The doctrine of act of state holds that a court in Country A does not necessarily refuse the adjudication of matters the government of Country $A$ has undertaken in other countries (Mcinerney, 2002, p. 82). This principle safeguards that an Indigenous American nation does not engage in activities outside of its territory that run counter to the Indigenous American nation's concepts categorized as law in the Occident. However, it would create an opening for settler colonial states to undermine an Indigenous American nation's concepts categorized as law in the Occident in the Indigenous American nation's territory thus maintaining existing coloniality.

Transnationalism may be required to create a foundation of citizenship and political legitimacy of Indigenous American nations extending into several states as the result of colonial borders. However, e.g., Kymlicka (2004, pp. 110-111) has rejected transnationalism as a foundation of citizenship and political legitimacy.

The principle of renvoi, i.e., the use of the law of Country B by a court in Country $A$, can result in (additional) unpredictability. This underlines the need for equal and separate Indigenous American equivalents to courts, and Occidental courts.

The principle of le principle de proximité, i.e., the principle of the most significant relationship, allows for finding a solution when both Indigenous American concepts categorized as law in the Occident and Occidental law can be considered applicable. In the case of equal and separate courts, a way to resolve a jurisdictional dispute needs to be devised. Considering Alonso de la Vera Cruz' and Francisco de Vitoria's determination of the illegality of the conquest of the Americas, a reasonable solution would be to establish an Indigenous American precedence.

An issue scarcely addressed in assessments of ius cogens, i.e., a part of international public law establishing ethical boundaries and from which derogation is forbidden, is that the procedures and substance of ius cogens are of Occidental origin, e.g., Virally (1966, p. 7). Whereas ius cogens can be considered the emergency break in international law, decolonial modifications are needed to prevent that ius cogens becomes a tool of a colonial fifth column. The importance of decolonial modifications is underlined by Eller's (2014, pp. 191-192) finding that sovereignty and territoriality in law have declined as a result of globalization.

\subsection{Indigenous American equivalent of law}

A conundrum emerges when an Occidental legal scholar endeavors to study Indigenous American law, because the scholar erroneously presupposes that the criteria of what constitutes law in the Occident are also valid in Indigenous American nations (Barrera Rosales, 2018, pp. 328-330). Even within the Occident, problems arise from linguistic and terminological differences (López Rodríguez, 2018, p. 182). Such incompatibilities are more severe in a cross-cultural context. The concept of critical and discursive legal pluralism provides the foundation for the argument that there is a diverse authorship in law that makes Indigenous American, among others, authorship of law cogent (Barrera Rosales, 2018, p. 329; Díaz Ocampo and Antúnez Sánchez, 2018, p. 57). 
A contentious issue between Indigenous Americans and Occidentals is the legality and legitimacy of the current landownership and resource ownership in the Americas. Alonso de la Vera Cruz' and Francisco de Vitoria's determination that the conquest of the Americas by Occidentals was illegal is key in the assessment of the current situation. There are three fundamental issues. First, Indigenous Americans contrary to Roman Law - historically do not recognize private landownership. In keeping with Immanuel Kant, the absence of the institution of landownership does not mean that the land would not belong to Indigenous Americans (Kleingeld, 1997, p. 340). Second, Roman Law recognizes ab initio, i.e., something without owner becomes the finder's property. Terra nullius has been claimed by the Occident to create the prerequisite for $a b$ initio -a claim that was patently absurd in the Americas in 1492 and later. Third, ownership is established via possession after two years in the case of land (usucapio), but this is not the case if the land was stolen (Adame Goddard, 2017, pp. 83-91). As a result, Indigenous Americans still own - in the Occidental sense of the term -all of the Americas. A fait accompli as tried to argue by Alonso de la Vera Cruz' is not a legal argument.

The combination of Alonso de la Vera Cruz' and Francisco de Vitoria's determination that the conquest of the Americas by Occidentals was illegal in combination with limitations to usucapio in Roman Law also raises the question of the legal status of Occidentals in the Americas since 1492. It can be argued that Occidentals have been illegals. If this were the case, then it would have far-ranging implications in the context of settler colonialism in the Americas. E.g., all laws passed by settler colonists would be null and void ex tunc on the grounds that the settler colonists did not have legal authority to pass them. Democratic, Habermasian and Rawlsian processes would not change such a conclusion for two reasons. First, as illegals Occidentals would have no legal authority to participate in democratic, Habermasian and Rawlsian processes in the Americas. Second, Occidentals being in the majority in several states means that democracy would be illegitimate as it would cement an unethical situation -this is an instance of different outcomes caused by colonialism in Africa and Asia on the one hand, and settler colonialism in the Americas on the other hand. Thus, the settler colonial legal system as a societal power system, and ethics and Roman law part ways in spite of having the same historical roots. The settler colonial legal systems attempt to defend the societal status quo even in the face of being ethically and legally problematic.

Indigenous American concepts categorized as ethics and law in the Occident do not prohibit conquests and military action per se. The wars conducted by the Aztecs in Mesoamerica before 1492 (Hernández Vaca, 2005, p. 117) provide evidence for this. The difference between Indigenous Americans and Occidentals was that the Indigenous Americans did not engage in significant cultural and epistemic racism as evidenced by the cultural and epistemic continuity evident in Mesoamerica prior to 1492 (Hernández Vaca, 2005, p. 141-142), and the Occidentals' cultural and epistemic racism -as exhibited by the destruction of the Aztec amoxcalli (libraries) (Armendáriz Sánchez, 2009, p. 85) -in the aftermath of 1492. The Romanization of particularly the societal elites in the Roman Empire (Kotula and Michalak, 1976, p. 342; Andrades Rivas, 2017, p. 62) can be interpreted to have laid the foundation for the Occidental cultural and epistemic racism that proved detrimental to Indigenous American cultures and epistemes in the aftermath of 1492. Simultaneously, the classical Roman Empire scrupulously respected the cultures and religions in the provinces (Kotula and Michalak, 1976, p. 342) evidencing a significant degree of tolerance. It is therefore possible to legitimize cultural and legal pluralism on the foundation of the Occident's Greco-Roman Heritage. 
The concept of critical and discursive legal pluralism provides a foundation for the assessment and finding solutions in the context of incompatible Indigenous American and Occidental concepts of what is categorized as ethics in the Occident. This can be denominated critical and discursive ethical pluralism.

\section{Indigenous American Concepts}

Which Indigenous American concepts call for critical and discursive pluralism? This cannot be conclusively answered in a journal paper, because there are hundreds of Indigenous American nations in the Americas -e.g., González Galván (1997, p. 525) has pointed to the resulting complexity. The historical influence of the Chichimeca and Toltecs in addition to the interrelationships between the Mexica nations in the $15^{\text {th }}$ century epitomizes the complex dynamics giving rise to the Mesoamerican cultures and epistemes (Navarrete Linares, 2017, p. 106). When the manifold Indigenous American concepts categorized as ethics and law in the Occident are studied, it is warranted to recall that the point is not the individual differences but totally different premises, and this makes them impossible to study with Occidental concepts (incommensurability) (González Galván, 1997, pp. 527-529). Potential incommensurability, fear and bias need to be taken into account when $16^{\text {th }}$ century written sources are considered -issues not fully recognized in, e.g., León-Portilla (2017, pp. 26-51).

Descola (2005, pp. 402-422) has presented four ontological categories influencing what is categorized as ethics in the Occident: Analogism, animism, naturalism and totemism. Analogism -found in Mesoamerica and the Andean worldentails according to Descola (2005, pp. 351-401) that all beings are singular thus there being no meaningful distinction between different species, and that comparisons between beings are based on analogy. Animism -found in northern North America and tropical South America- holds that all beings have a spirit in spite of appearing in different corporealities thus gainsaying a distinction between humans and other beings. Naturalism -found in the Occident- presupposes that externally all beings descend from the same ancestor, but only humans possess ethics and souls. Totemism -found in North America- engenders that beings are considered on the basis of their physical, psychic, and moral characteristics. Descola (2005, pp. 254301 ) has concluded that solely naturalism is founded on the dichotomy humans versus other beings, and that analogism, animism and totemism do not give humans ontological exclusivity. Kawaguchi and Guimarães (2019, pp. 375-396) have concluded that Indigenous Americans view all beings to be part of the same culture with different beings having dissimilar perspectives -this is referred to as perspectivism. Occidentals consider nonhuman beings as exploitable objects and threats (Kawaguchi and Guimarães, 2019, pp. 375-396). The premises of what is categorized as ethics and law in the Occident are therefore different among Indigenous Americans and Occidentals.

It has been concluded that -contrary to the Occidentals- Indigenous Americans do not focus on economic growth, and consider land communal property (Barrera Rosales, 2018, pp. 515-522). The notion of non-human co-essence-referred to as nahualli in Mesoamerica (Martínez González, 2017)- underlines the symbiosis of humanity and Nature among Indigenous American nations. For the Maya, the human body and Nature are both part of a sacred single territory (Morales Damián, 2010 , p. 279). It is warranted to recall that broad categories have a tendency of not being nuanced.

An obstacle in Occidental research into Indigenous American thinking is that building the necessary relationships needed in the research of oral traditions is more 
challenging than validation of research on the foundation of Occidental theory (Gaudet, 2014, pp. 81-83). It has been argued that Occidental journals act as gatekeepers defending the status quo characterized by Occidental dominance (Mihesuah and Wilson, 2002, p. 148) -this discourages research into, e.g., the manifold Indigenous American concepts categorized as ethics and law in the Occident. The resulting scholarly asymmetry has a tendency to effectively legitimize extant racism, and cultural and epistemic racism directed against Indigenous Americans. Now, some examples of Indigenous American concepts are discussed.

From among the disparate Indigenous American concepts categorized as ethics in the Occident, concepts of the North American Cree, and South American Aymara, Quechua and U'wa are discussed. Instead of thinking along philosophical and religious lines like in the Occident, the Indigenous American U'wa, among others, think along spiritual and symbolic lines (Gómez Pardo, 2006, pp. 15-18). The spiritual and symbolic foundation of U'wa thinking effectively translates into holism of humans and Nature. Oil extraction cannot realistically be reconciled with, e.g., U'wa thinking oil is the blood of Mother Earth and its extraction kills Mother Earth (Gómez Pardo, 2006, p. 16). The Aymara and Quechua consider humans to be parts of a holistic network of connections encompassing humanity and Nature (Púa Mora, 2006, pp. 5354). The Cree equivalent to Occidental ethics contains the concept of wakohtowin -a concept founded on the thought of a circle that reflects the equality of all people, and their capability to care for, heal, nurture and protect the land and the people (Settee, 2011, pp. 441-447). The holism in Indigenous American thinking is effectively incompatible with the Occidental exploitative attitude vis-à-vis Nature.

The equality expressed in wakohtowin is developed further in pimatisiwin. The Cree foreground community life, sharing of values and wellbeing -this is reflected in the Cree concept of pimatisiwin- in addition to the emphasis on good relationships within an extended community -this is reflected in the Cree concept of miyowichihtowin (Settee, 2011, pp. 437-438). Miyo-wichihtowin and pimatisiwin are effectively diagonally opposite to Occidental individualism.

The claim of the existence of globally valid human rights in, e.g., Meyer (1995, pp. 189-194) is problematic on two counts. First, the concept of "rights" has its own Occidental history and does not necessarily have any meaning outside of the Occident. Second, the issue of individuals versus nations has been solved in fundamentally incompatible ways in, e.g., Cree wakohtowin and Occidental ethics. This underlines the need for the equality of Indigenous American and Occidental concepts categorized as ethics in the Occident.

Indigenous American analogism, animism, perspectivism and totemism effectively contain a significant degree of equality between human and other beings. An equality of all beings contributes to four far-reaching conflicts of ethics. First, human and other beings have equal rights to the use of the land. This renders, e.g., the erection of fences limiting the movement of non-human beings unacceptable. Second, human and non-human beings have equal rights to the yield of the land. Any human scheme reducing the yield of the land as a result of, e.g., environmental damage is thus unacceptable. Third, human and other beings have concurrent, equal and parallel ownership rights to the land -sole human ownership is an Occidental concept. Depriving the land from non-human beings would amount to an unacceptable confiscation, because human beings cannot unilaterally impose their will on nonhuman beings. Fourth, the lives and wellbeing of human and non-human beings are protected making any human scheme that endangers the lives and wellbeing of nonhuman beings unacceptable. Conflicts of ethics arise not only in the context of the extraction of natural resources and the emission of compounds with detrimental effects 
on human and non-human beings either directly or indirectly, but conflicts of ethics also arise in the context of the desirability of material growth. The inequality of human and non-human beings implicitly contained in the Occidental concept of sustainable development renders it a candidate for conflict of ethics.

The concept of integration of Indigenous Americans (Salinas Burgos, 1986, p. 504 ) is called into question by research into cultural and epistemic racism. When does integration factually become cultural and epistemic racism? Of particular concern are situations when Indigenous American thinking clashes with Occidental natural resource extraction (Gómez Pardo, 2006, p. 17). There is thus no common ground needed for Habermasian or Rawlsian processes.

\section{Navigating Conflict of Ethics}

The settler colonialism in the Americas creates the challenge that there oftentimes is no clear territorial demarcation. This adds an additional layer of complexity. How can the clash between manifold Indigenous American concepts categorized as ethics and law in the Occident on the one hand and Occidental ethics and law on the other hand be navigated? There are two alternative responses. First, one of the two is determined superior with all the associated ethical pitfalls. Considering the illegality of the conquest of the Americas determined by Alonso de la Vera Cruz and Francisco de Vitoria, and the obvious absurdity of any terra nullius claim, it is founded to give Indigenous American concepts categorized as ethics and law in the Occident precedence. From an Occidental perspective, this solution is legitimate in view of the arrangements in the Roman Empire.

Second, both manifold Indigenous American concepts categorized as ethics and law in the Occident, and Occidental ethics and law are considered equal. If clashes between the two arise, then the conflict of ethics is resolved with the use of principles modelled on the legal principles used in the case of conflict of laws, particularly nationality versus territoriality, judicial restraint, transnationalism, ordre public, crown act of state, renvoi, proximité, and ius cogens. From an Occidental standpoint, this solution is legitimized by the arrangements in the Germanic kingdoms.

In order to work, the equality of manifold Indigenous American concepts categorized as ethics and law in the Occident, and Occidental ethics and law requires that the equality is accepted as ius cogens on all sides. Because of the lack of clear territorial boundaries between Indigenous Americans and Occidentals in settler colonies, territoriality is unworkable. This means equality but not sameness of indigenous Americans and Occidentals. The principles of judicial restraint and renvoi require in ethics and law that Occidentals refrain from attempts to influence ethical and legal assessments by Indigenous Americans. The application of the principle of proximité in ethics and law may be effectively limited to negotiations between Indigenous American nations and Occidental government bodies.

The discourse on Indigenous Americans is different from minority rights in one important point according to d'Errico (1999, p. 9): Indigenous Americans are claiming a separate domain thus making the discourse into one on sovereignty. There is no fundamental ground to reject the division of sovereignty within a state (Robbins, 2010, pp. 258-261). This would allow the formation of more or less sovereign Indigenous American nations within a state. Such a solution contains three flaws. First, Indigenous Americans have legal and legitimate claims to all of the Americas. Second, an establishment of Indigenous American nations within a state would create the challenge with the associated discrimination against Indigenous Americans not living within the boundaries of these entities -e.g., reserves. Third, the colonial boundaries 
separate Indigenous American nations, e.g., the Aymara live in Bolivia, Chile and Peru, and the Maya live in Belize, Guatemala, Honduras, Mexico and El Salvador. Therefore, sovereign Indigenous American nations and Occidental states exist interlocked and simultaneously in the Americas.

To wrap up: In settler colonalism, decoloniality means added complexity in the navigation of ethical and legal issues. Firms cannot rely on democratic, Habermasian and Rawlsian processes to yield outcomes that are congruent with Indigenous American concepts categorized as ethics and law in the Occident because of settler colonialism. Firms' compliance with Occidental law may be unethical if this violates Indigenous American concepts categorized as ethics and law in the Occident. Decoloniality in settler colonies requires from firms complex analyses as to what is acceptable by both Indigenous American concepts categorized as ethics in the Occident and Occidental ethics. Firms need to deal with interlocked sovereign Indigenous American nations and sovereign Occidental states in the Americas. An increasingly important ethical challenge is to incorporate the interlock and simultaneity into artificial intelligence.

\section{Conclusion}

The objective of this paper is to develop and present a novel approach to the conflict of ethics on the foundation of legal theory, particularly the legal rules governing conflict of law. The focus of this paper is the conflict of ethics impacting Indigenous Americans. Whereas the Indigenous American experience is characterized by settler colonialism, the dynamics of racism, and cultural and epistemic racism are different from those found in Africa and Asia.

This paper contains three major contributions. First, the interplay between Indigenous American concepts categorized as ethics in the Occident and Occidental ethics in a settler colonial context is assessed. Second, Occidental concepts in Roman Law and Saint Thomas Aquinas' natural law are used to determine the precedence of Indigenous American concepts categorized as ethics in the Occident. Third, rulesbased solutions derived from conflict of laws in international law are applied to conflict of ethics in the settler colonial context are synthetized.

Additional research is required on four issues. First, research into manifold Indigenous American concepts categorized as ethics and law in the Occident are still in their infancy and require more attention in ethics and legal research. Second, research into Indigenous American oral traditions has received limited attention in ethics and legal research, and needs to be developed. Third, corruption and violence undermining Indigenous American concepts categorized as ethics and law in the Occident have received insufficient attention in ethics and legal research. Fourth, the divergent Indigenous American nations' concepts on solving territorial conflicts and joint use need to be studied.

Determining that the conquest of the Americas was illegal and legitimizing the resulting status quo as a fait accompli as done by Alonso de la Vera Cruz and Francisco de Vitoria raises ethically troubling issues. It is incumbent on ethics and legal research to find ways to eliminate the racism, and cultural and epistemic racism directed against Indigenous American nations by settler colonialism. 
Bibliography

Adame Goddard, J. C. (2017). Curso de derecho romano clásico. México DF, México: Porrúa.

Andrades Rivas, E. (2017). La transformación de la ciudadanía romana en el fin del Imperio. Revista de Estudios Histórico-Jurídicos, (39), pp. 61-83.

Armendáriz Sánchez, S. (2009). Los códices y la biblioteca prehispánica y su influencia en las bibliotecas conventuales en México. Biblioteca Universitaria, 12(2), pp. 83-103.

Ary, A. (2014). Ética e direito: Que diálogo? Revista Portuguesa de Filosofia, 70(2/3), pp. 539-552.

Barrera Rosales, P. (2018). El elemento indígena en la relación entre el lus Constitutionale Commune en América Latina y el derecho económico internacional. En A. von Bogdandy, P. Salazar Ugarte, M. Morales Antoniazzi y F. C. Ebert (eds.), El constitucionalismo transformador en América Latina y el derecho económico internacional (pp. 311-330). México DF, México: Universidad Nacional Autónoma de México.

Battcock, C. (2016). Las guerras y las conquistas en la Crónica mexicana. Estudios de Cultura Náhuatl, (52), pp. 169-192.

Bazán, V. (2004). Los derechos de los pueblos indígenas en clave de derecho interno e internacional. Estudios Constitucionales, 2(1), pp. 37-98.

Becerra Ramírez, M. (2017). Las fuentes contemporáneas del derecho internacional. México DF, México: Universidad Nacional Autónoma de México.

Bermúdez Abreu, Y. y Quintero, Y. (2007). La "declaración" de los derechos indígenas. Revista de Derecho, (28), pp. 43-70.

Camacho Negrete, R. A. (2012). Jurisdicción de equidad. Revista Boliviana de Derecho, (13), pp. 169-174.

Churchill, W. (1985). The situation of Indigenous populations in the United States: A contemporary perspective. Wicazo Sa Review, 1(1), pp. 30-35.

d'Errico, P. (1999). Native Americans in America: A theoretical and historical overview. Wicazo Sa Review, 14(1), pp. 7-28.

Descola P. (2005). Par-delà nature et culture. Paris, Francia: Gallimard.

Díaz Ocampo, E. y Antúnez Sánchez, A. (2018). El constitucionalismo en América Latina: La justicia indígena y el pluralismo jurídico en Ecuador. Pensamiento Jurídico, (47), pp. 43-76.

Eller, K. H. (2014). Rechtskritik durch Vertrag: Zu den Semantiken des transnationalen Rechts. Kritische Vierteljahresschrift für Gesetzgebung und Rechtswissenschaft, 97(3), pp. 191-216.

Emanuelli, C. (2010). Droit international public. Montréal, Canadá: Wilson \& Lafleur.

Estrada, J. A. (2006). Por un cristianismo inculturado en una Iglesia autóctona. Revista Iberoamericana de Teología, (3), pp. 5-26.

Estrada Ochoa, A. C. (2009). Naturaleza, cultura e identidad: Reflexiones desde la tradición oral maya contemporánea. Estudios de Cultura Maya, 34, pp. 181-201.

Fox-Decent, E. and Dahlman, I. (2015). Sovereignty as trusteeship and Indigenous peoples. Theoretical Inquiries in Law, 16(2), pp. 507-534.

Garzón López, P. (2018). Colonialidad (jurídica). Eunomía: Revista en Cultura de la Legalidad, (14), pp. 206-214.

Gaudet, J. C. (2014). Rethinking participatory research with Indigenous peoples. Native American and Indigenous Studies, 1(2), pp. 69-88.

Gaviria Gil, M. V. (2013). El derecho occidental del siglo XXI y el concepto de familia jurídica. Revista de Derecho, 39, pp. 30-57.

Gérard, G. (2012). Hegel, lecteur de la métaphysique d'Aristote. Revue de métaphysique et de morale, 74(2), pp. 195-223.

Giesen, K.-G. (2013). La philosophie. En T. Balzacq y F. Ramel (eds.), Traité de relations internationels (pp. 411-438). Paris, Francia: Presses de Sciences Po. 
Gómez Pardo, R. (2006). Los U'wa y la "Ética de Hegel": Un ensayo "deconstructivo" sobre el punto de vista del otro. Franciscanum: Revista de las ciencias del espíritu, (144), pp. 11-29.

Grosfoguel, R. (2004). Race and ethnicity or racialized ethnicities? Identities within global coloniality. Ethnicities, 4, pp. 315-336.

Gschwend, L. (2009). La conquista española y la idea de los derechos humanos en la obra de Bartolomé de Las Casas (1484-1566). Pensamiento Jurídico (24), pp. 39-78.

Guénaire, M. (2001). La common law ou l'avenir d'une justice sans code. Le Débat, 115(3), pp. 49-54.

Hernández Vaca, J. (2005). La administración comunitaria del pueblo azteca. Estudios Políticos, 8(6), pp. 113-144.

Kawaguchi, D. and Guimarães, D. S. (2019). Is everybody human? The relationship between humanity and animality in Western and Amerindian myth narratives. Culture \& Psychology, 25(3), pp. 375-396.

Kleingeld, P. (1997). Kants politischer Kosmopolitismus. Jahrbuch für Recht und Ethik, 5, pp. 333-348.

Kohler, J. (1917). Die spanischen Naturrechtslehrer des 16. und 17. Jahrhunderts. Archiv für Rechts- und Wirtschaftsphilosophie, 10(3), pp. 235-263.

Kotula T. And Michalak M. (1976). Les Africains et la domination de Rome. Dialogues d'histoire ancienne, 2, pp. 337-358

Kymlicka, W. (2004). Le mythe de la citoyenneté transnationale. Critique internationale, (23), pp. 97-111.

Le Goff, J. (2008). La civilisation de l'Occident medieval. Paris, Francia: Flammarion.

León-Portilla, M. (1983). Antología: De Teotihuacán a los aztecas. México DF, México: Universidad Nacional Autónoma de México.

Léon-Portilla, M. (2017). La filosofía náhuatl estudiada en sus fuentes. México DF, México: Universidad Nacional Autónoma de México.

Lepelley, C. (1998). L'Afrique. En C. Lepelley (ed.), Rome et l'intégration de l'Empire (pp. 71-112). Paris, Francia: Presses universitaires de France.

López Rodríguez, A. M. (2018). Operating across national and linguistic borders. Journal of Private International Law, 14(1), pp. 182-192.

Macarón, P. M. (2017). Propiedad indígena: Reivindicación de tierras ancestrales. Buenos Aires, Argentina: Astrea.

Macnair, M. (2007). Equity and conscience. Oxford Journal of Legal Studies, 27(4), pp. 659-681.

Mako, S. (2012). Cultural genocide and key international instruments: Framing the Indigenous experience. International Journal on Minority and Group Rights, 19(2), pp. 175-194.

Martínez González, R. (2017). El nahualismo. México DF, México: Universidad Nacional Autónoma de México.

Massini-Correas, C. I. (2019). Sobre iusnaturalismo y validez del derecho. Díkaion: Revista de Fundamentación Jurídica, 28(1), pp. 7-34.

Mayer, A. (2014). El pensamiento de Bartolomé de las Casas en el discurso sobre el indígena: Una perspectiva comparada en las colonias Americanas. Historia Mexicana, 63(3), pp. 1121-1179.

Mcinerney, T. (2002). The regulation of bribery in the United States. Revue Internationale de Droit Pénal, 73(1), pp. 81-107.

Memmi, A. (2014). Racism. Minneapolis, EE.UU: University of Minnesota Press.

Meyer, W. H. (1995). Toward a global culture: Human rights, group rights and cultural relativism. International Journal on Minority and Group Rights, 3(3), pp. 169-195.

Mihesuah, D. A. y Wilson, A. C. (2002). Indigenous scholars versus the status quo. American Indian Quarterly, 26(1), pp. 145-148.

Montargot, N. and Peretti, J.-M. (2014). Regards de responsables sur les notions d'égalité, non-discrimination et diversité. Revue Management et Avenir, (68), pp. 
183-200.

Morales Damián, M. A. (2010). Territorio sagrado: Cuerpo humano y naturaleza en el pensamiento maya. Cuicuilco, 17(48), pp. 279-298.

Müller, W. G. (2006). Medieval Church law as a field of historical inquiry. En W. P. Müller y M. E. Sommar (eds.), Medieval Church law and the origins of the Western legal tradition (pp. 1-16). Washington, EE.UU: Catholic University of America Press.

Navarrete Linares, F. (2017). Los orígenes de los pueblos indígenas del valle de México. México DF, México: Universidad Nacional Autónoma de México.

Oberkofler, A. (2006). Richterliche Tätigkeit im US-amerikanischen Rechtssystem aus dem Blickwinkel der Critical Legal Studies. Archiv für Rechts- und Sozialphilosophie, 92(2), pp. 209-222.

Olivier-Martin, F. (2010). Histoire du droit français. Paris, France: CNRS.

Ollero, A. (2002). Rawls' politischer Liberalismus, Moral und Recht. Archiv für Rechtsund Sozialphilosophie, 88(2), pp. 269-278.

Orellana, F. C. (2005). Concepciones eurocéntricas: Negación del otro y exclusión social como imposibilidad de desarrollo. Sociedad Hoy, (8-9), pp. 87-94.

Pachón Soto, D. (2012). Historiografía, eurocentrismo y universalidad en Enrique Dussel. Ideas y Valores, 61(148), pp. 37-58.

Pereznieto Castro, L. (2015). El derecho internacional privado y su normatividad en su incorporación en el sistema jurídico mexicano. Anuario Mexicano de Derecho Internacional, 15, pp. 773-816.

Perrin, C. (2007). Egalité et réciprocité. Le Philosophoire, 29(2), pp. 259-280.

Pfordten, D. von der (2012). Über Begriffe im Recht. Archiv für Rechts- und Sozialphilosophie, 98(4), pp. 439-456.

Púa Mora, F. G. (2006). Antropología filosófica amerindia. Franciscanum: Revista de las ciencias del espíritu, (144), pp. 47-58.

Quijano, A. (2007). Coloniality and modernity/rationality. Cultural Studies, 21(2-3), pp. $168-178$.

Quintana Osuna, K. I. y Góngora Maas, J. J. (2017). Los derechos de los pueblos indígenas y tribales en los sistemas de derechos humanos. México DF, México: Universidad Nacional Autónoma de México.

Renner, M. (2010). Paradigmen des Antidiskriminierungsrechts. Kritische Vierteljahresschrift für Gesetzgebung und Rechtswissenschaft, 93(2), pp. 161167.

Robbins, J. (2010). A nation within? Indigenous peoples, representation and sovereignty in Australia. Ethnicities, 10(2), pp. 257-274.

Roca, M. J. (1997). Eine europäische Geschichte der Rechts- und Staatsphilosophie. Juristenzeitung, 52(18), pp. 881-886.

Romero Seguel, A. (2012). La adecuación de procedimiento en materia de derecho indígena. Revista Chilena de Derecho, 39(3), pp. 819-828.

Rosa, F. M. S. C. Da. (2015). A invenção do índio. Espaço Ameríndio, 9(3), pp. 257277.

Salah, M. M. (2010). Droit économique et droit international privé. Revue internationale de droit économique, 24(1), pp. 9-36.

Salinas Burgos, H. (1986). Las poblaciones indígenas en el derecho internacional. Revista Chilena de Derecho, 13(3), pp. 503-523.

Settee, P. (2011). Indigenous knowledge: Multiple approaches. Counterpoints, 379, pp. 434-450.

Silva Alonso, R. (1972). La norma de conflicto como regla instrumental. Revista Española de Derecho Internacional, 25(1/4), pp. 361-367.

Tuori, K. (2013). Vers une théorie du droit transnational. Revue internationale de droit économique, 27(1), pp. 9-36.

Villey, M. (2002). Le droit romain. Paris, France: Presses Universitaires de France.

Virally M. (1966). Réflexions sur le "jus cogens". Annuaire français de droit 
international, 12, pp. 5-29.

Westra, H. (2010). The defense of Native title and dominion in sixteenth-century Mexico compared with Delgamuukw. En L. A. Knafla y H. Westra (eds.), Aboriginal title and Indigenous peoples: Canada, Australia, and New Zealand (pp. 100-107). Vancouver, Canadá: UBC Press.

Winkel, L. (2015). Deux conceptions du droit naturel dans l'Antiquité. Revue historique de droit français et étranger, 93(3), pp. 341-350.

Zimmermann, R. (2007). Römisches Recht und europäische Kultur. Juristenzeitung, 62(1), pp. 1-12. 